\title{
Civilizační nemoci - daň za moderní způsob života
}

Depresivní poruchy, jejich vzájemný vztah s kardiovaskulárními (KV) chorobami a chronické žilní onemocnění (CVD) byly jako typické civilizační nemoci dnešní doby tématem jednoho ze sympozií společnosti Servier na Výročním sjezdu České kardiologické společnosti v květnu 2021.

Doc. Anders ve své přednášce poukázal na velmi vysoký podíl nemocných s KV onemocněním, kteří současně trpí afektivními poruchami. Zdůraznil, že takové pacienty je třeba vyhledávat a v př́padě indikace léčit vhodnými antidepresivy, protože neléčená depresivní epizoda významně ovlivňuje riziko KV př́hod a celkovou mortalitu. Je třeba mít také na paměti, že některé kardiologické léky mohou mít depresogenní efekt. A jak uvedl, antidepresiva nejsou homogenní skupinou pro léčbu depresivní poruchy u pacientů s KV onemocněním. Preferovány jsou SSRI a při preskripci specialistou Ize využít i moderní antidepresiva s robustními důkazy o KV bezpečnosti, jako je agomelatin.

Doc. Karetová se věnovala chronickému žilnímu onemocnění, které bývá často podceňováno i přesto, že pro pacienta představuje progredující a recidivující doživotní problém. CVD může svými příznaky snižovat kvalitu života a bez léčby vést k závažným komplikacím, jako jsou bércové vředy. Mezinárodní doporučení pro diagnostiku a léčbu CVD zdůrazňují potřebu včasného záchytu, využití duplexní ultrasonografie v diagnostice a včasnou aplikaci jednotlivých terapeutických modalit včetně venofarmak podle úrovně důkazů. Nejkvalitnější důkazy z farmakoterapeutických možností má mikronizovaná purifikovaná flavonoidní frakce (Detralex ${ }^{\circledast}$ ), která je jako jediné venofarmakum doporučena u stadia C6 s otevřeným bércovým vředem.

\section{Depresivní poruchy u kardiovaskulárních onemocnění}

doc. MUDr. Martin Anders, Ph.D.

(Psychiatrická klinika 1. LF UK a VFN Praha)

Vzájemný vztah mezi depresivní poruchou a kardiovaskulárními chorobami

Mezi civilizační nemoci, které dnešní doba přináší, patří psychické poruchy. Zátěž daná těmito poruchami se vyjadřuje jako počet ztracených let života z důvodu dané nemoci. V posledních letech stoupá především zátěž daná depresivními poruchami a demencí (1). Roční prevalence duševních onemocnění včetně lehkých psychických poruch dosahuje v Evropě ohromujících 38\% (2).

Bylo prokázáno, že výskyt depresivní poruchy významně ovlivňuje délku života u mužů i u žen (3). Ve věku 45 let zkracuje prítomnost deprese očekávanou délku života o 9,5 roku u mužů a o 8,3 roku u žen. Zvýšená mortalita depresivních pacientů přitom nejde na vrub suicidality. Je dána především současným výskytem somatických onemocnění, zejm. kardiovaskulárních.

Bylo prokázáno, že počet somatických onemocnění je prediktorem výskytu depresivní poruchy, a platí, že čím větším počtem tělesných onemocnění pacient trpí, tím má vyšší riziko výskytu afektivní poruchy (4). Výskyt depresivní poruchy u pacientů, kteři mají nejméně 4 somatická onemocnění, stoupá až na $72 \%$. Této skupině nemocných je proto třeba věnovat náležitou pozornost a po projevech emoční poruchy u nich pátrat. Obecně předpokládáme vysoký výskyt deprese u pacientů s onkologickým onemocněním. Dosahuje 33-42\%. Méně je ale známo, že u pacientů s KV onemocněním je toto číslo ještě vyšší. Deprese je prítomna u $47 \%$ pacientů po cévní mozkové příhodě (CMP) a u $45 \%$ pacientů po infarktu myokardu (IM) (5). Po IM je výskyt depresivních epizod jedním z nejvýznamnějších prognostických faktorů délky přežití srovnávaným svým významem se snížením ejekční frakce.

U KV onemocnění byla zjištěna i opačná závislost. Pozitivní anamnéza depresivního onemocnění nebo výskyt depresivních príznaků jsou prediktorem výskytu KV príhod (6, 7). Deprese zvyšuje 10letou mortalitu pacientů $\mathrm{s}$ ischemickou chorobou srdeční (ICHS) a prítomnost deprese po IM vede k významnému nárůstu mortality v následujících 5 letech, což je dopad, který nebyl zjištěn u úzkosti nebo zlosti (obr. 1) (8). Doložena byla také souvislost mezi sníženým pozitivním afektem (hedonií, tj. chybění radosti ze života, radosti z aktivit apod.) a mortalitou nebo výskytem IM během 2 let po zavedení stentu (9). Chybění pozitivní afektivity má možná ještě větší dopad než prítomnost depresivní nálady. Naopak léčba antidepresivy může riziko KV přihod snižit. V Rotterdam study vedlo aktuální uživání selektivních inhibitorů zpětného vychytávání serotoninu (SSRI) a tricyklických antidepresiv (TCA) ke snížení incidence IM (10).

Patofyziologické mechanismy vysvětlující souvislost kardiovaskulárních onemocnění a depresivních poruch

Vzájemná souvislost mezi depresivními poruchami a KV chorobami je komplexní. Lze ji vysvětlit biologickými mechanismy, jako je neuroendokrinní alterace, autonomní dysregulace, imunozánětlivé změny, aktivita trombocytů a endoteliální dysfunkce, ale také působením životního stylu, kdy se uplatňuje vliv kouření, abúzus alkoholu, obezita, nedostatek fyzické aktivity, nezdravá strava, zanedbávání péče o vlastní zdraví či non-adherence k léčbě (11). 
Obr. 1. Mortalita pacientů po infarktu myokardu v závislosti na př́tomnosti úzkosti, zlosti, malé sociální podpory a deprese (8)
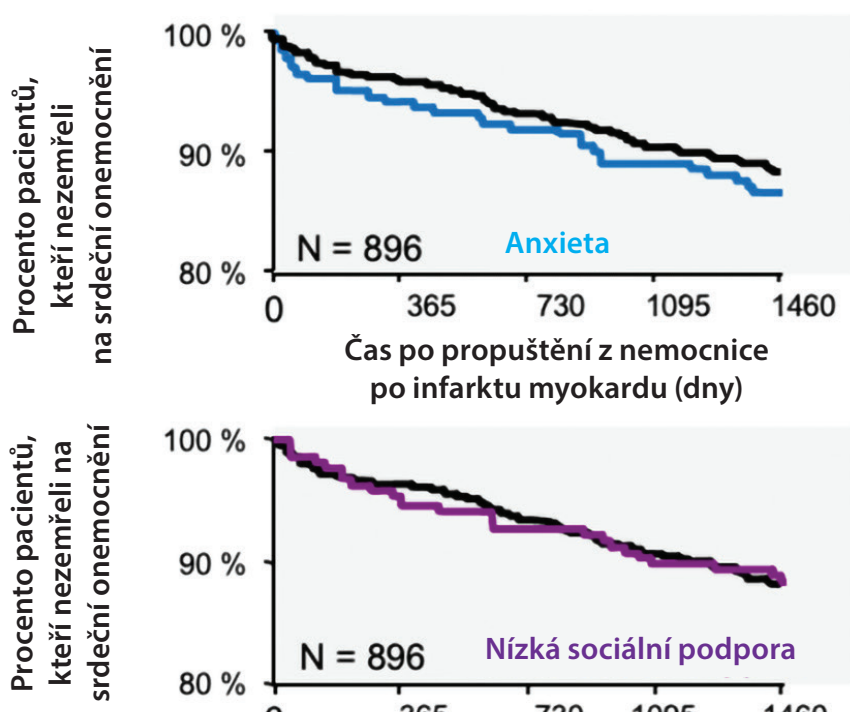

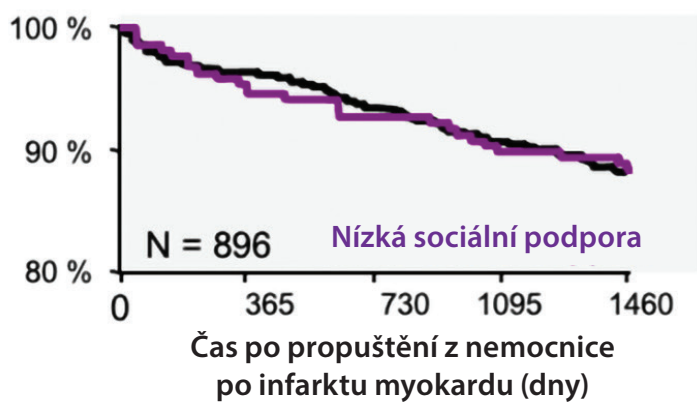

BDI - Beckova sebeposuzovací stupnice deprese

Byly popsány tři základní osy interakcí mezi KV systémem a psychickými poruchami:

1) zvýšení sympatomedulární aktivity,

2) změny $v$ aktivitě autonomního vegetativního systému (snížení vagového tonu, pokles variability srdeční frekvence, zvýšení variability krevního tlaku),

3) zvýšení reaktivity trombocytů (lidské trombocyty mají transportéry pro vychytávání serotoninu totožné s neurony).

Důležitým pojítkem mezi KV onemocněním a depresí jsou cytokiny, např. interleukin $1 \beta$, interleukin 6 , tumor necrosis factor a (TNF a) a C-reaktivní protein (CRP). Tyto cytokiny významně ovlivňují tzv. „neuronální processing". Dưsledkem mưže být změna afektivity, která není způsobena stresem ani zevními okolnostmi, ale čistě biologickými vlivy.

Zvýšenou aktivitu cytokinů způsobuje nízkoaktivní zánět, a tyto cytokiny ovlivňují dostupnost tryptofanu pro tvorbu serotoninu a melatoninu (12). Infekce a vyplavení cytokinů tedy může touto cestou ovlivnit afektivitu a cirkadiánní rytmy. Během zánětu jsou také produkovány neurotoxické látky, např. kyselina chinolinová, která ovlivňuje činnost mozku a neuroneogenezi. Mozek reaguje na aktivaci imunitního systému změnou funkčního stavu některých oblastí, jako je zejm. gyrus cingulí (Brodmannova area 25), který je zapojen do modulace afektivity. Tento efekt byl pozorován u zdravých osob po aplikaci tyfoidní vakcíny (13). U citlivých jedinců může vlivem infekce dojít až k rozvoji duševního onemocnění.

Systémový chronický nízkoaktivní zánět je suspektním procesem patofyziologie řady onemocnění. Popsané souvislosti psychiatrických poruch se zánětem odpovídá i nový koncept v psychiatrii nazvaný „inflamed mind“" Z něho vychází doporučení řešit a léčit všechny chronické zánětlivé změny.
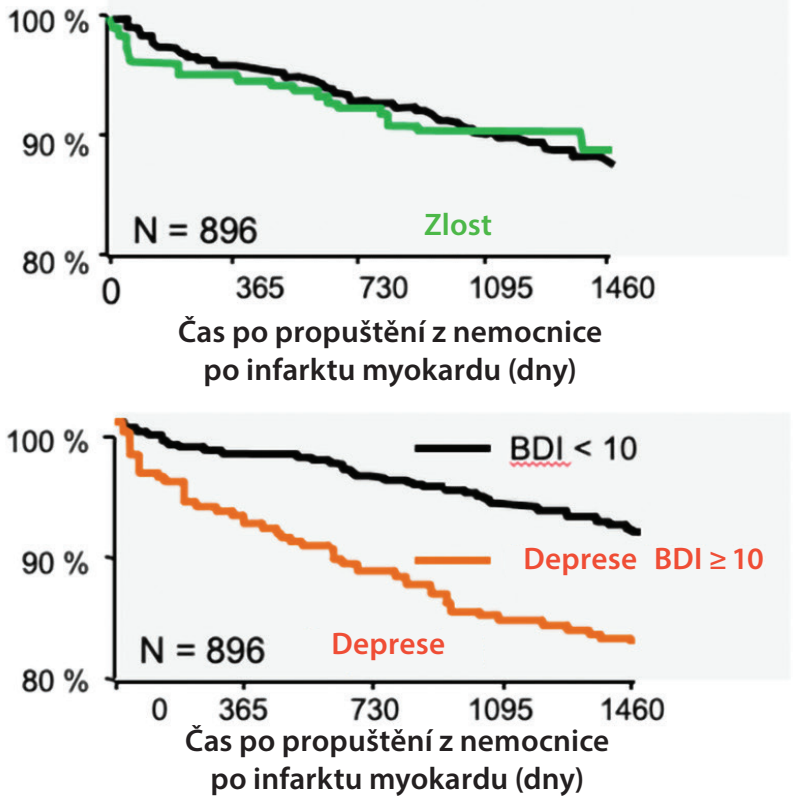

Terapeutická doporučení u pacientů s KV onemocněním a depresí

Vzhledem k výše uvedeným faktům je u pacientů s KV onemocněním důležité provádět screening deprese. Pokud je depresivní porucha zjištěna, jsou v prítomnosti KV onemocnění nejpoužívanějšími antidepresivy SSRI. Jsou účinná i v léčbě depresivní poruchy po KV príhodě a nenarušují srdeční funkce. U lehké nebo středně těžké depresivní epizody je prínosem psychoterapie (v monoterapii nebo v kombinaci s antidepresivy). Při výběru antidepresiva u nemocných s KV onemocněním je samožrejmě důležitá jejich KV bezpečnost. Tab. 1 ukazuje vliv nejpoužívanějších antidepresiv na rưzné KV parametry. Bylo zjištěno, že u pacientů s KV chorobami snižuji SSRI riziko IM o 70\%, zatímco TCA jen o 4\% (17). Jeden z mechanismů, jakým tohoto prínosu SSRI dosahují, bude nejspíše zahrnovat trombocyty obsahující serotoninový transportér. U pacientů s ICHS + depresivní poruchou byla zjištěna významně zvýšená aktivita trombocytů v porovnání s kontrolami i s jedinci se samotnou ICHS (18). Léčba SSRI prokázala snižení trombocytárního faktoru 4 i $\beta$-tromboglobulinu. TCA tento efekt nevykazují (19).Podávání anxiolytik ke snížení rizika IM nevede (20). Důležité je u pacientů s KV onemocněním léčených pro depresivní poruchu monitorovat adherenci, účinnost a bezpečnost léčby jak somatického, tak psychického onemocnění.

Při volbě preventivní kardiovaskulární léčby u pacientů s depresí je třeba mít na paměti, že existuje řada KV léčiv, která mohou mít depresogenní účinek. Zahrnují clonidin, digitalis, guanetidin, hydralazin, methyldopu, procainamid, propranolol, reserpin a thiazidová diuretika (21).

\section{Agomelatin - antidepresivum vhodné u pacientů s KV onemocněním}

Jedním z moderních antidepresiv mimo skupinu SSRI, která jsou vhodná u pacientů s KV onemocněním, je agomelatin. Má jedinečný mechanismus účinku - působí prostřednictvím melatoninergních receptorů a specifických serotoninergních receptorů. Ve studii PULSE s 896 pacienty, 
Tab. 1. Vliv nejpoužívanějšich antidepresiv na jednotlivé KV parametry (18)

\begin{tabular}{|c|c|c|c|c|c|c|}
\hline AD & TF & TK & QTc & arytmie & převod.p. & pozn. \\
\hline agomelatin & 0 & 0 & 0 & 0 & $?$ & $\downarrow$ data \\
\hline bupropion & $(\uparrow)$ & $\begin{array}{c}\uparrow \\
\text { rare } \downarrow\end{array}$ & $\begin{array}{c}\downarrow \\
\text { predávk. } \uparrow\end{array}$ & 0 & 0 & $\begin{array}{l}\text { interakce } \\
\text { TK monit. }\end{array}$ \\
\hline citalopram (escitalopram) & $\downarrow$ & $(\downarrow)$ STK & $\uparrow$ (dávka) & $\begin{array}{c}\text { TdP } \\
\text { (předávk.) }\end{array}$ & 0 & $\uparrow \mathrm{QTC}$ \\
\hline fluoxetin & $\downarrow$ & $\min$. & 0 & 0 & 0 & bezbečný po IM \\
\hline fluvoxamin & $\min$. & $\downarrow$ STK & 0 & 0 & 0 & změny EKG? \\
\hline IMAO & $\downarrow \downarrow$ & $\begin{array}{c}\downarrow \\
\text { risk HK }\end{array}$ & $?$ & $\stackrel{+}{+}$ & 0 & NE u KVO \\
\hline mirtazapin & $\min$. & $\min$. & 0 & 0 & 0 & bezpečný po IM \\
\hline moklobemid & $(\downarrow)$ & $\min$. & $\begin{array}{c}0 \\
\text { predávk. } \uparrow\end{array}$ & 0 & 0 & $\begin{array}{c}\text { cave } \\
\text { předávk. }\end{array}$ \\
\hline paroxetin & $\downarrow$ & $\min$. & 0 & 0 & 0 & bezpečný po IM? \\
\hline sertralin & $\min$. & $\min$. & 0 & 0 & 0 & bezpečný u KVO \\
\hline trazodon & $\begin{array}{l}\downarrow \downarrow \\
\uparrow \\
\end{array}$ & $\downarrow$ & $(\uparrow)$ & + & $?$ & $\begin{array}{c}\text { cave } \\
\text { (arytmie) }\end{array}$ \\
\hline TCA & $\uparrow \uparrow$ & $\downarrow \downarrow$ & $\uparrow$ & $\begin{array}{l}\text { ventr. a. } \\
\text { TdP }\end{array}$ & $\begin{array}{l}\text { zpomalují } \\
\text { převod }\end{array}$ & $\begin{array}{l}\text { KI u KVO } \\
\text { ICHS, NSS }\end{array}$ \\
\hline venlafaxin & $(\uparrow)$ & $\uparrow$ & $\begin{array}{c}0 \\
\text { předávk. } \uparrow\end{array}$ & rare & rare & $\begin{array}{l}\text { bezpečný } \\
\text { u ICHS? }\end{array}$ \\
\hline vortioxetin & 0 & 0 & 0 & 0 & 0 & $\downarrow$ data \\
\hline
\end{tabular}

$A D=$ antidepresivum, EKG = elektrokardiografie, HK = hypertenzní krize, ICHS = ischemická choroba srdečni, IM = infarkt myokardu, KI = kontraindikace, NSS = náhlá srdeční smrt, STK = systolický tlak krve, TdP = torsade de pointes, TF = tepová frekvence, TK = krevní tlak, KVO = kardiovaskulárni onemocnění

kteří trpěli depresivní poruchou a zároveň somatickými chorobami zahrnujícími KV onemocnění, diabetes, chronickou obstrukční plicní nemoc (CHOPN) a neurologická onemocnění, prokázal agomelatin vynikající bezpečnost a zmírnění depresivní i úzkostné symptomatiky (obr. 2) (22).

\section{Závěr}

Depresivní porucha postihuje nezanedbatelnou část pacientů trpících kardiovaskulárními chorobami. Prítomnost depresivní poruchy prìtom urychluje rozvoj těchto somatických onemocnění, zhoršuje negativní prognostický význam, snižuje odpověd’ na léčbu a zvyšuje mortalitu. Je spojena se sniženou kvalitou života a vyššími náklady na léčbu. Po výskytu depresivní poruchy je proto třeba u pacientů s KV onemocněním cíleně pátrat, zjištěnou depresi adekvátně léčit a její léčbu monitorovat. Antidepresiva nejsou homogenní skupinou pro léčbu depresivní poruchy u pacientů s KV onemocněním. Preferovány jsou SSRI a při preskripci specialistou Ize využít i nejmodernější antidepresiva s doloženou KV bezpečností, jako je agomelatin. Je třeba myslet na to, že některé kardiologické léky mohou mít depresogenní efekt a některá psychofarmaka mají kardiovaskulární nežádoucí účinky.

\section{LITERATURA}

1. GBD 2017 Disease and Injury Incidence and Prevalence Collaborators. Global, regional, and national incidence, prevalence, and years lived with disability for 354 diseases and injuries for 195 countries and territories, 1990-2017: a systematic analysis for the Global Burden of Disease Study 2017. Lancet. 2018; 392(10159): 1789-1858.

2. Wittchen HU, Jacobi F, Rehm J, et al. The size and burden of mental disorders and other disorders of the brain in Europe 2010. Eur Neuropsychopharmacol. 2011; 21(9): 655-679.

3. Laursen TM, Musliner KL, Benros ME, et al. Mortality and life expectancy in persons with severe unipolar depression. J Affect Disord. 2016; 193: 203-207.

4. Markkula N, Härkänen T, Nieminen T, et al. Prognosis of depressive disorders in the general population- results from the longitudinal Finnish Health 2011 Study. J Affect Disord. 2016; 190: 687-696

5. Birrer RB, Vemuri SP. Depression in later life: a diagnostic and therapeutic challenge. Am Fam Physician. 2004; 69(10): 2375-2382.
Obr. 2. Agomelatin prokázal bezpečnost a účinnost v léčbě depresivní poruchy u pacientư se somatickými chorobami včetně kardiovaskulárních onemocnění (22)
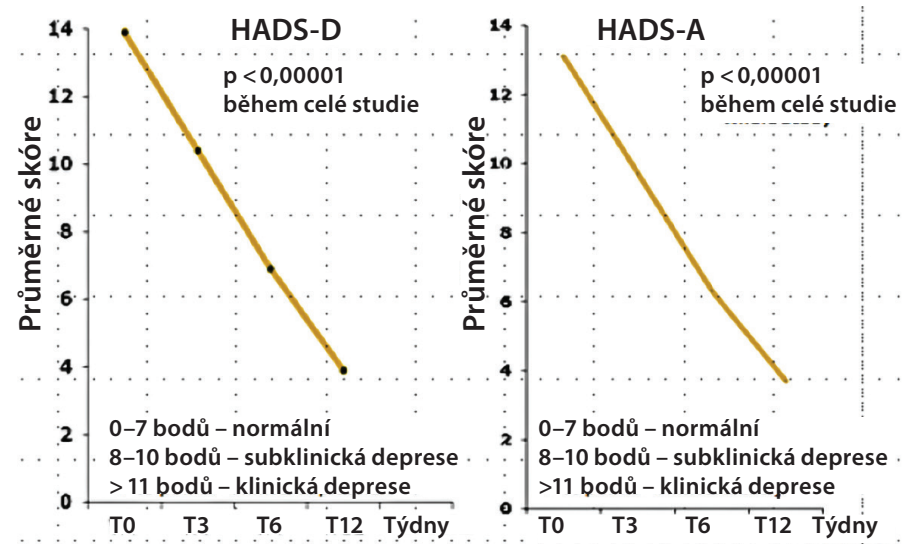

HADS = nemocniční škála pro hodnocení deprese a anxiety (Hospital Anxiety and Depression Scale), $D=$ deprese, $A=$ anxieta

6. Larsen KK, Christensen B, Søndergaard J, Vestergaard M. Depressive symptoms and risk of new cardiovascular events or death in patients with myocardial infarction: a population-based longitudinal study examining health behaviors and health care interventions. PLoS One. 2013; 8(9): e74393 7. Daskalopoulou M, George J, Walters K, et al. Depression as a Risk Factor for the Initial Presentation of Twelve Cardiac, Cerebrovascular, and Peripheral Arterial Diseases: Data Linkage Study of 1.9 Million Women and Men. PLoS One. 2016; 11(4): e0153838.

8. Frasure-Smith N, Lespérance F. Depression--a cardiac risk factor in search of a treatment. JAMA. 2003; 289(23): 3171-3173.

9. Denollet J, Pedersen SS, Daemen J, et al. Reduced positive affect (anhedonia) predicts major clinical events following implantation of coronary-artery stents. J Intern Med. 2008; 263(2): 203-211. 10. Noordam R, Aarts N, Leening MJ, et al. Use of antidepressants and the risk of myocardial infarction in middle-aged and older adults: a matched case-control study. Eur J Clin Pharmacol. 2016; 72(2): 211-218. 


\section{NOVINKY V KARDIOLOGII}

\section{CIVILIZAČNÍNEMOCI - DAŇ ZA MODERNÍZZPUSOB ŽIVOTA}

11. Penninx BW. Depression and cardiovascular disease: Epidemiological evidence on their linking mechanisms. Neurosci Biobehav Rev. 2017; 74(Pt B): 277-286.

12. Leonard B, Maes M. Mechanistic explanations how cell-mediated immune activation inflammation and oxidative and nitrosative stress pathways and their sequels and concomitants play a role in the pathophysiology of unipolar depression. Neurosci Biobehav Rev 2012: 36(2): 764-785

13. Harrison NA, Brydon L, Walker C, et al. Inflammation causes mood changes through alterations in subgenual cingulate activity and mesolimbic connectivity. Biol Psychiatry. 2009; 66(5): 407-414.

14. Amidfar M, Woelfer M, Réus $\mathrm{GZ}$, et al. The role of NMDA receptor in neurobiology and treatment of major depressive disorder: Evidence from translational research. Prog Neuropsychopharmacol Biol Psychiatry 2019; 94: 109668.

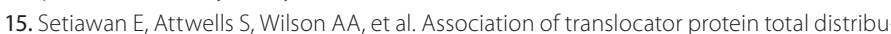
tion volume with duration of untreated major depressive disorder: a cross-sectional study Lancet Psychiatry. 2018; 5(4): 339-347.

16. Ramasubbu R, Taylor VH, Samaan Z, et al; Canadian Network for Mood and Anxiety Treatments (CANMAT) Task Force. The Canadian Network for Mood and Anxiety Treatments
(CANMAT) task force recommendations for the management of patients with mood disorders and select comorbid medical conditions. Ann Clin Psychiatry 2012; 24(1): 91-109.

17. Cohen HW, Gibson G, Alderman MH. Excess risk of myocardial infarction in patients treated with antidepressant medications: association with use of tricyclic agents. Am J Med. 2000; 108(1): 2-8.

18. Laghrissi-Thode F, Wagner WR, Pollock BG, et al. Elevated platelet factor 4 and beta-thromboglobulin plasma levels in depressed patients with ischemic heart disease. Biol Psychiatry 1997; 42(4): 290-295.

19. Markovitz PJ. Recent trends in the pharmacotherapy of personality disorders. J Pers Disord. 2004; 18(1): 90-101.

20. Sauer WH, Berlin JA, Kimmel SE. Selective serotonin reuptake inhibitors and myocardia infarction. Circulation. 2001; 104(16): 1894-1898.

21. Birrer RB, Vemuri SP. Depression in later life: a diagnostic and therapeutic challenge. Am Fam Physician. 2004; 69(10): 2375-2382.

22. Medvedev VE. Agomelatine in the treatment of mild-to-moderate depression in patients with cardiovascular disease: results of the national multicenter observational study PULSE. Neuropsychiatr Dis Treat. 2017; 13: 1141-1151.

\section{Zánět a chronická žilní onemocnění, jedna z epidemií 21. století doc. MUDr. Debora Karetová, CSc. (II. interní klinika kardiologie a angiologie, Komplexní kardiovaskulární centrum VFN a 1. LF UK Praha)}

\section{Chronické žilní onemocnění}

Chronické žilní onemocnění (CVD z anglického chronic venous disorder) je strukturální nebo funkční postižení žlního systému chronického charakteru, které se manifestuje symptomy anebo nálezy vyžadujícími lékařské vyšetření a případnou zdravotní péči (1). Dřive používaný pojem chronická žilní insuficience odpovídá stavu pokročilých známek nemoci, jako jsou varixy, edémy, kožní změny či bércové vředy (stadium C3-C6 CVD). Jde o velmi časté onemocnění, které může v počátečních stadiích působit banálně, prričemž oba tyto faktory vedou k jeho častému podceňování.

Rizikové faktory CVD jsou často neovlivnitelné. Zahrnují věk, genetické vlivy, ženské pohlaví, povolání, hormonální změny, habitus, výskyt chronického kašle, obstipace a dalších komorbidit. CVD má zpočátku benigní charakter, ovšem svými symptomy již v počátečních stadiích nepříznivě ovlivňuje kvalitu života. Proto je důležité včas identifikovat první projevy a přiznaky, správně určit jejich etiologii a zahájit léčbu. Jde totiž o onemocnění chronické a recidivující, které v pozdějších stadiích vede k ireverzibilním změnám a je provázeno obtížně léčitelnými dlouhodobými až invalidizujícími komplikacemi.

Symptomy CVD bývají nespecifické. Pacienti popisují únavu dolních končetin, pocit těžkých nohou, občasný výskyt otoků (zpočátku jen perimaleolárně), pálení, štípání, svědění, svalové křeče či neklidné nohy. Intenzita příznakủ kolísá, obvykle jsou horší večer a v horkém počasí. Objektivní známky se vyvíjejí od drobných teleangiektazií, přes retikulární varixy, kmenové varixy, intermitentní edémy, permanentní otok, hyperpigmentace, lipodermatosklerózu, ekzémy při stasis dermatitis, po bílou atrofii a bércové vředy.

\section{Stadia CVD}

Chronické žilní onemocnění rozdělujeme do 7 stadií (CO-C6). Klasifikace vznikla v roce 2004 (1) a naposledy byla aktualizována v roce 2020 (2). Má zkratku CEAP, protože vychází z klinických (clinical), etiologických, ana- tomických a patologických charakteristik onemocnění (tab. 1) (2). Mezi novinky v aktuální klasifikaci patří rozdělení kožních změn (u stadia (4) na 3 podtřídy: C4a (pigmentace, ekzém), C4b (lipodermatoskleróza, atrofie), C4c (corona phlebectatica). Teleangiektazie v oblasti vnitřního kotníku (corona phlebectatica paraplantaris) jsou nově považovány za jasný důkaz žilní hypertenze a jsou přeřazeny z klinické kategorie C1 do C4c. Přidána byla kategorie recidivujících varixů a ulcerací (C2r a C6r), které jsou projevem pokročilé dysfunkce žilního systému a mohou svědčit pro nedostatečnost léčby. Dále byla rozdělena etiologická kategorie sekundárních varixů na podskupinu vyvolanou intravenózními príčinami (Esi) a extravaskulárními př́činami, tj. zevní útlak cévy, (Ese). Zavedeny byly rovněž subkategorie neznámá etiologie (En) a bez prokázané žilní patofyziologie (Pn), kdy ale musí být prítomny typické symptomy CVD.

\section{Patogenetické mechanismy rozvoje CVD}

V žilním systému se nacházejí 2/3 krve přitomné v lidském organismu. Jde o nízkotlaký rezervoár, jehož úkolem je návrat krve k srdci. Na zajištění žilního návratu z dolních končetin proti gravitaci se podílí několik mechanismů:

- svalově žilní pumpa (pohyb),

- podtlak v dolní duté žíle při nádechu,

- tonus žilní stěny + žilní chlopně,

- normální funkce pravé a levé komory srdeční.

Až 90\% krve z dolních končetin odvádí hluboký žilní systém, 10\% povrchový žilní systém (3). Je potřebná souhra 4 faktorư: průchodnost hlubokých žil, funkční žilní chlopně při dobrém žilním tonu, normální kloubně-svalové funkce (žilní pumpa) a normální hemodynamické poměry.

Rozvoj a progrese CVD je komplexní (4).Začíná genetickými predispozicemi, vlivem prostředí, metabolismu a životního stylu. Hemodynamické poruchy, jako je zvýšený venózní hydrostatický tlak a abnormální střižné napětí (shear stress), vedou k distenzi žilní stěny, žilnímu refluxu a rozvoji insuficience žilních chlopní. Současně dochází k poškození funkce endotelu s následným zvýšením permeability žilní stěny a nerovnováhou vazoaktivních faktorů (NO, PGI2). Nadměrná aktivace endotelu a poškození glykokalyxu aktivuje leukocyty, které infiltrují žilní stěnu a vyplavují prozánětlivé mediátory a protrombotické molekuly. Rozvijí se zánět. Ten společně s remodelací žilní 


\section{INZERCE}




\section{NOVINKY V KARDIOLOGII}

CIVILIZAČNÍNEMOCI - DAÑ ZA MODERNÍZZPUSOB ŽIVOTA

stěny (aktivace metaloproteináz) vede k hyperpolarizaci endotelu, relaxaci hladkého svalstva žilní stěny a degradaci extracelulární matrix. Následkem těchto změn je dilatace a tortuozita žilní stěny, které přispívají kžilnímu refluxu a nedomykavosti žilních chlopní. Uzavírá se bludný kruh. Výsledkem je patologická propustnost žilní stěny, rozvoj zánětu v intersticiu, přetížení lymfatického systému a také lokální protrombotická aktivace (5).

\section{Bércové vředy a jiné komplikace CVD}

Včasná diagnostika a léčba CVD může zabránit rozvoji vážných komplikací, jako jsou trombóza povrchové žily (varikoflebitis), flebotrombóza hlubokých žil, krvácení z varixů a zejména vzniku žilních bércových vředů. Kožní ulcerace z cévních př́čin tvoří asi $90 \%$ všech kožních defektů, přičemž většina z nich je venózní etiologie. Bércové vředy žilní etiologie, které se typicky vyskytují v oblasti vnitřního kotníku nebo bérce, jsou mělké s nepravidelnými okraji, bývají provázeny mírnou až střední bolestí a obvykle je prítomna také hyperpigmentace a lipodermatoskleróza. Arteriální bércové vředy vznikají spíše v oblasti aker a v místech otlaku. Mívají nekrotickou spodinu a jsou provázeny silnou bolestí. Palpačně zjištujeme slabou tepennou pulzaci. Naopak nebolestivé bývají bércové vředy neuropatické etiologie. Vznikají v místě otlaku a bývají typicky vpáčené. Př́tomna je obvykle porucha čití.

\section{Diagnostika léčba CVD}

Nedílnou součástí diagnostiky CVD je vedle anamnézy a klinického vyšetření duplexní ultrasonografie, pomocí níž lze znázornit anatomii a funkci žilního systému. Používá se k prokázání průchodnosti a prípadné insuficience hlubokých a povrchových žil, k zobrazení perforátorů, zpřesnění anatomických poměrů a lokalizaci a určení velikosti refluxu.

Léčba CVD by měla být zaměřena na žilní hypertenzi a sterilní zánět v žilní stěně a v intersticiu. Možnosti nefarmakologické léčby zahrnují režimová opatření (chůzi a cvičení, polohování dolních končetin, péči o kưži a redukci tělesné hmotnosti) a také kompresní léčbu. Tyto terapeutické metody jsou ale spojeny s nízkou adherencí. U řady pacientů může být důležitou součástí léčby chirurgický zákrok. Možnosti zahrnují:

- skleroterapii, tj. destrukci endotelu žíly aplikací detergentní látky,

- stripping povrchových žilních kmenů spojený s crossektomií a flebektomií,

- endovenózní zákroky:

- endovenózní laserovou ablaci (EVLT),

- radiofrekvenční ablaci (RFA),

- ablaci povrchových žilních kmenů pomocí prehřáté páry,

- netumescentní netermální metody:

- mechanicko-chemickou ablaci (MOCA),

- použití biologického lepidla (VenaSeal).

Po výkonu je nutná komprese. Všechny chirurgické postupy jsou spojeny s 5letým rizikem recidivy okolo $20 \%$ (6).

U všech pacientů s př́znaky CVD je vhodné podávat venofarmaka. Tyto prípravky zvyšuji žilní tonus a chrání žilní chlopně, svými účinky na lymfatický systém podporují lymfatickou drenáž a působí také na úrovni mikrocirkulace, kde snižují kapilární permeabilitu a aktivaci leukocytů. Rovněž vykazují mírný antitrombotický efekt, kterého dosahují prostřednictvím zvýšení fibrinolýzy a snížení hladiny plazminogenu.
Tab. 1. Klasifikace chronického žilního onemocnění CEAP (1)

\begin{tabular}{|c|c|}
\hline Charakteristiky & \\
\hline $\begin{array}{l}\text { C } \\
\text { klinické }\end{array}$ & $\begin{array}{l}\text { C0 - nejsou viditelné ani hmatné abnormity } \\
\text { C1 - teleangiektázie nebo retikulární varixy } \\
\text { C2 - varixy } \\
\text { C2r - rekurentní varixy } \\
\text { C3 - edém } \\
\text { C4 - hyperpigmentace nebo ekzém } \\
\text { C4a - pigmentace nebo ekzém } \\
\text { C4b - lipodermatoskleróza nebo atrofie } \\
\text { C4C - corona phlebectatica } \\
\text { C5 - zhojený vřed } \\
\text { C6 - aktivní vřed } \\
\text { C6r - rekurentní aktivní vřed } \\
\text { +S - symptomatické; }+\mathbf{A} \text { - asymptomatické }\end{array}$ \\
\hline $\begin{array}{l}\text { E } \\
\text { etiologické }\end{array}$ & $\begin{array}{l}\text { Ep - primární (neznámá etiologie) } \\
\text { Es - sekundární: Esi (intravenózní), Ese (extravenózní) } \\
\text { Ec - kongenitální } \\
\text { En - nezjištěna př́čina }\end{array}$ \\
\hline $\begin{array}{l}\text { A } \\
\text { anatomické }\end{array}$ & $\begin{array}{l}\text { As - superficiální systém } \\
\text { Ad - hluboký (deep) systém } \\
\text { Ap - perforátory; An - anatomická lokace nezjištěna }\end{array}$ \\
\hline $\begin{array}{l}\mathrm{P} \\
\text { patologické }\end{array}$ & $\begin{array}{l}\text { Pr - reflux } \\
\text { Po - obstrukce } \\
\text { Pr+o - kombinace refluxu s obstrukcí } \\
\text { Pn - patofyziologie nezjištěna }\end{array}$ \\
\hline
\end{tabular}

Obr. 1. Varovné a pokročilé projevy CVD

Klinické projevy CVD „VAROVNÉ““

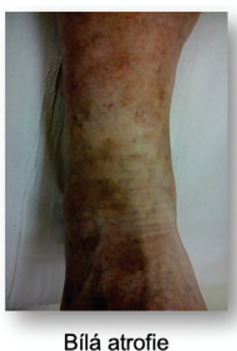

epigmente

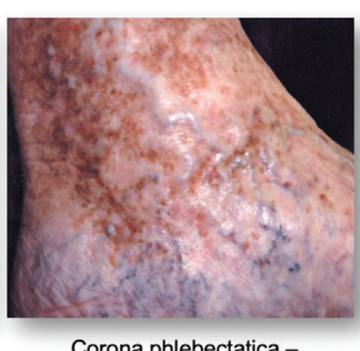

Corona phlebectatica dilatované dermální venuly v oblasti vnitřního kotníku

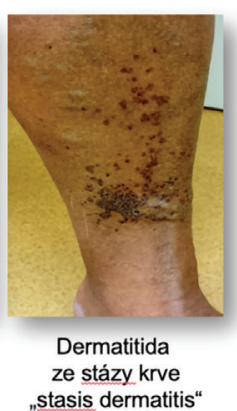

stasis dermatitis

\section{Klinické projevy CVD „POKROČILÉ““}

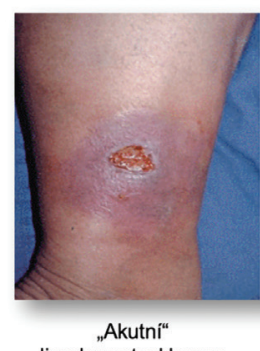

lipodermatosklerosa

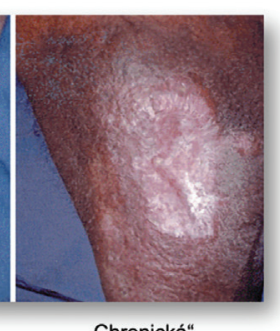

"Chronická" lipodermatosklerosa

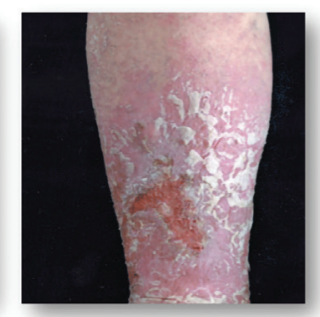

Erytém a deskvamace kưže v okolí ulcerózní dermatitidy
Současná mezinárodní i národní doporučení pro diagnostiku a léčbu CVD uvádějí jako venofarmakum s nejvyšší silou důkazů mikronizovanou purifikovanou flavonoidní frakci (MPFF, Detralex ${ }^{\circledR}$ ), a to ve všech stadiích onemocnění, od prvních přiznaků až po stadium otevřeného bércového vředu (tab. 2) $(6,7)$. Důležité je používat přednostně venofarmaka, která mají pozitivní důkazy o účinnosti, protože u řady tradičních léků tyto chybí (7). MPFF má vysoce klinicky doložený komplexní protizánětlivý, venoprotektivní a antiedematózní účinek $(5,6,7)$. 
NOVINKY V KARDIOLOGII I

CIVILIZAČNÍ NEMOCI - DAŇ ZA MODERNÍ ZPŮSOB ŽIVOTA

Tab. 2. Souhrn doporučení pro podávání venofarmak ve stadiích COs-C6 podle systému GRADE $(6,7)$

\begin{tabular}{|c|c|c|c|c|}
\hline Indikace & Venofarmakum & Doporučení pro užití & Průkaz účinku & Síla důkazů \\
\hline \multirow{9}{*}{$\begin{array}{l}\text { Úleva symptomů } \\
\text { chronické žilní onemocnění } \\
\text { u nemocných v tříách } \\
\text { dle CEAP: C0s-C6s }\end{array}$} & mikronizovaná purifikovaná flavonoidní frakce (MPFF®) & silné & střední & $1 \mathrm{~B}$ \\
\hline & nemikronizovaný diosmin nebo syntetický diosmin & slabé & slabý & $2 \mathrm{C}$ \\
\hline & rutosidy & slabé & střední & 2B \\
\hline & extrakty z vinné révy (Vitis vinifera) & slabé & střední & 2B \\
\hline & kalcium dobesilát & slabé & střední & 2B \\
\hline & extrakt z jírovce mad’alu (koňský kaštan, Aesculus hippocastanum) & slabé & střední & 2B \\
\hline & extrakt z listnatce ostnitého (Ruscus aculeatus) & slabé & střední & 2B \\
\hline & extrakt z jinanu dvoulaločného (Gingko biloba) & slabé & slabý & $2 C$ \\
\hline & jiná venofarmaka & slabé & slabý & $2 \mathrm{C}$ \\
\hline $\begin{array}{l}\text { Hojení žilních ulcerací (CEAP - C6), } \\
\text { prídatně ke kompresi a lokální léčbě }\end{array}$ & $\mathrm{MPFF}^{\oplus}$ & silné & střední & $1 \mathrm{~B}$ \\
\hline
\end{tabular}

\section{Závěr}

CVD je progredující a recidivující choroba charakterizovaná sterilním zánětem žilní stěny a intersticia. Nelze ji považovat za kosmetický problém daný prítomností varixů či otoků. Svými přiznaky může toto onemocnění totiž značně snižovat kvalitu života a bez léčby vést k závažným, až invalidizujícím komplikacím. Progresi CVD do pozdních stadií

\section{LITERATURA}

1. Eklof B, Perrin M, Delis KT, et al. American Venous Forum; European Venous Forum; International Union of Phlebology; American College of Phlebology; International Union of Angiology. Updated terminology of chronic venous disorders: the VEIN-TERM transatlantic interdisciplinary consensus document. J Vasc Surg. 2009; 49(2): 498-501.

2. Lurie F, Passman M, Meisner M, et al. The 2020 update of the CEAP classification system and reporting standards. J Vasc Surg Venous Lymphat Disord. 2020; 8(3): 342-352.

3. Tansey EA, Montgomery LEA, Quinn JG, et al. Understanding basic vein physiology and venous blood pressure through simple physical assessments. Adv Physiol Educ. 2019; 43(3): 423-429.

4. Ligi D, Croce L, Mannello F. Chronic Venous Disorders: The Dangerous, the Good, and the Diverse. Int J Mol Sci. 2018; 19(9): 2544.
Ize předcházet kombinací adekvátních terapeutických postupů. Ty Ize snadněji a s nižšími náklady volit při včasném zahájení léčby. Zahrnují režimová opatření, farmakoterapii, kompresní léčbu a u indikovaných pacientů i invazivní zákrok. Z venofarmak má největší sílu důkazů pro léčbu všech stadií chronického žilního onemocnění mikronizovaná purifikovaná flavonoidní frakce.

5. Mansilha A, Sousa J. Pathophysiological Mechanisms of Chronic Venous Disease and Im plications for Venoactive Drug Therapy. Int J Mol Sci. 2018; 19(6): 1669

6. Nicolaides A, Kakkos S, Baekgaard N, et al. Management of chronic venous disorders of the lower limbs. Guidelines According to Scientific Evidence. Part I. Int Angiol. 2018; 37(3): 181-254.

7. Karetová $D$, et al. Doporučené diagnostické a terapeutické postupy pro všeobecné praktické lékaře - chronické žilní onemocnění. Centrum doporučených postupů pro praktické lékaře. SVL ČLS JEP. Novelizace 2021.

Pripravila MUDr. Zuzana Zafarová 